\title{
UIT DE REDACTIE
}

\section{Waardeer de historicus die het publiek opzoekt}

\author{
Lieke Smits
}

Uit de redactie. In deze rubriek schrijven redacteurs van het Tijdschrift voor Geschiedenis beurtelings over actuele thema's of gebeurtenissen in de historische wereld die hen bezighouden.

Afgelopen januari was de historische discipline plots onderwerp van het publieke debat in Vlaanderen. In landelijke dagbladen en op televisie vond discussie plaats over de respectievelijke merites van academische geschiedschrijving en populaire publieksgeschiedenis. Vertegenwoordiger van deze tweede tak van sport was Bart Van Loo, auteur van de historische bestseller $D e$ Bourgondiërs.

De discussie kwam op gang na een kritisch stuk van vakhistorici Lisa Demets en Jelle Haemers in De Standaard waarin zij Van Loos nadruk op de 'grote mannen' van de geschiedenis en zijn gebrek aan bronnenkritiek hekelden. Dit leidde tot een weerwoord waarin Van Loo zich afvroeg: waarom doen deze historici dan zelf niet aan 'narratieve geschiedschrijving' in boeken voor een groot publiek? In het antwoord dat hij zelf op deze vraag formuleerde richtte hij zijn pijlen op het universitaire systeem: een bestseller schrijven is voor academische historici haast onmogelijk, omdat dit tot weinig waardering leidt en zelfs carrières om zeep kan helpen.

Van Loos kritiek op deze 'systeemfout' vond weerklank bij academici en leidde zelfs tot vragen over 'de kloof tussen wetenschap en burger' in een commissievergadering van het Vlaams Parlement. Tegelijkertijd kwamen ook de nodige relativerende bespiegelingen voorbij. Historicus Jeroen Wijnendaele merkte bijvoorbeeld op dat veel experts hun inzichten al met het grote publiek delen. Dit gebeurt alleen lang niet altijd in bestsellers, maar vaak in andere vormen, zoals tentoonstellingen.

Nederlandse historici pakten deze specifieke discussie niet op. Hoogleraar Wetenschapscommunicatie Ionica Smeets verwees er wel naar in haar column in de Volkskrant. Zij kaartte het probleem aan dat niet alle reviewers toegankelijk taalgebruik in wetenschappelijke publicaties weten te waarderen. Dit punt gaat dus niet om populairwetenschappelijke publicaties, maar raakt wel aan de vraag hoe toegankelijk wetenschap moet en mag zijn. Nu open access de norm begint te worden, Tijdschrift voor Geschiedenis ging vorig jaar al om, is al een van de obstakels tussen wetenschap en publiek weggenomen. Zal deze ontwikkeling richting een toegankelijke wetenschap zich voortzetten in een aanpassing van het taalgebruik?

In Nederland werd ondertussen op diverse plekken een andere, gerelateerde discussie gevoerd. Op het jaarlijkse symposium 'Wetenschapsbloggers', in een KNAW-rapport over academische vrijheid in Nederland en in de diesoratie van hoogleraar Ineke Sluiter aan de Universiteit Leiden; op al deze plekken werd gesproken over de bijdragen van wetenschappers aan het maatschappelijke 
debat. Hier komen specifieke problemen bij kijken waar een historicus die een publieksboek schrijft wellicht niet mee te maken zal krijgen. Belangrijke vragen die naar voren kwamen: Waar ligt de grens van zaken waar je als wetenschapper je deskundige mening over mag geven? Hoe maak je duidelijk wat je als academicus zegt en wat als burger? En hoe kunnen universiteiten wetenschappers die zich in het publieke debat mengen beschermen tegen online haat?

Om een duurzame publieksgeschiedenis te waarborgen denk ik dat we de Vlaamse en Nederlandse discussies moeten voortzetten en met elkaar in dialoog brengen. Hierbij kan de vraag centraal staan: welke ondersteuning hebben historici nodig om te participeren in wetenschapscommunicatie en het maatschappelijke debat? Deze discussie kan leiden tot een grotere rol voor deze activiteiten in het wetenschappelijke financierings- en waarderingssysteem, maar ook tot andere vormen van ondersteuning voor historici die zich buiten de universiteit wagen, zoals mediatrainingen. Of dit tot meer historische bestsellers en andere vormen van popularisering door historici moet leiden is nog maar de vraag. Belangrijker is een duurzame publieksgeschiedenis in de breedste zin van het woord, en voldoende ondersteuning en waardering voor de historici die zich hiervoor inzetten.

\section{Over de auteur}

Dr. Lieke Smits is docent en onderzoeker aan de Universiteit Leiden, gespecialiseerd in de religieuze cultuur van de laatmiddeleeuwse Lage Landen. Daarnaast is ze verbonden aan het Ruusbroecgenootschap van de Universiteit Antwerpen.

E-mail:1.a.smits@hum.leidenuniv.nl 